\title{
Microbiological, serological and molecular diagnosis of abscess of withers in equine in the State of Pará
}

Diagnóstico microbiológico, sorológico e molecullar de abscessos de cernellha em equinos no Estado do Pará

Diagnóstico microbiológico, serológico y molecular de los abscesos en cruz de caballo en el Estado de Pará

Vitória Fonseca Rodrigues ORCID: https://orcid.org/0000-0003-2002-8222 Federal Rural University of the Amazon, Brazil

E-mail: vickfonsecarodrigues@gmail.com

Andrea Viana da Cruz

ORCID: https://orcid.org/0000-0002-6532-8424

Federal University of Pará, Brazil

E-mail: andrea.vianacruz@gmail.com

Elem Cristina Macedo Barra

ORCID: https://orcid.org/0000-0002-5799-8954 Federal Rural University of the Amazon, Brazil

E-mail: elem.c.m.b@gmail.com

Barbara Wilka Leal Silva

ORCID: https://orcid.org/0000-0002-4055-4302 Federal Rural University of the Amazon, Brazil

E-mail: leal.barbara193@gmail.com

Camila de Cássia dos Santos ORCID: https://orcid.org/0000-0002-7860-1565 Federal Rural University of the Amazon, Brazil

E-mail: camilamedvs@gmail.com

Keila Feitosa Valente ORCID: https://orcid.org/0000-0001-8965-5123 Federal Rural University of the Amazon, Brazil

E-mail: keilavalente.vet@gmail.com

Thamillys Rayssa Marques Monteiro ORCID: https://orcid.org/0000-0002-4763-5316 Federal Rural University of the Amazon, Brazil E-mail: thamillysmonteiro@gmail.com

Djacy Barbosa Ribeiro ORCID: https://orcid.org/0000-0002-7008-0259 Federal Rural University of the Amazon, Brazil E-mail: djufra@gmail.com

Cintya de Oliveira Souza ORCID: https://orcid.org/0000-0002-5496-3713

Evandro Chagas Institute, Brazil

E-mail: cintyaoliveira@iec.gov.br

Naiana Fleury da Fonseca Ampuero ORCID: https://orcid.org/0000-0002-9167-8698

Evandro Chagas Institute, Brazil E-mail: naianafleury@gmail.com

Loreno da Costa Francez ORCID: https://orcid.org/0000-0003-0299-8698 Federal Rural University of the Amazon, Brazil E-mail: lorenof@ig.com.br

Ana Judith Pires Garcia Quaresma ORCID: https://orcid.org/0000-0003-2613-7219

Evandro Chagas Institute, Brazil

E-mail: anaquaresma@iec.gov.br

Andréa Maria Góes Negrão ORCID: https://orcid.org/0000-0002-2064-0772 Federal Rural University of the Amazon, Brazil E-mail: andreamariagn@gmail.com 
Lívia Medeiros Neves Casseb

ORCID: https://orcid.org/0000-0001-8578-9984

Evandro Chagas Institute, Brazil

E-mail: liviacasseb@iec.pa.gov.br

Alexandre do Rosário Casseb

ORCID: https://orcid.org/0000-0001-5615-2423

Federal Rural University of the Amazon, Brazil

E-mail: alexcasseb@yahoo.com.br

\begin{abstract}
There are several infectious diseases that affect equines and can cause large economic losses in this sector and damage to animal welfare. In this species, abscessing lesions of a purulent character preferentially in the withers are strongly suggestive of brucellosis. However, few studies have been carried out on the disease in this species, making its identification and control difficult due to the lack of standardization in the interpretation of results. Therefore, samples of whole blood, serum and purulent secretion were collected from three horses. The animals came from the state of Pará. The diagnostic methods selected were the Rose-Bengal plate test (RBPT) and Polymerase Chain Reaction (PCR), for the negative molecular results for brucellosis, microbiological analysis were chosen. Although part of the samples were positive for brucellosis in serological tests, all of them showed negative results for PCR. In bacterial cultivation, species were isolated Streptococcus equi subsp. zooepidemicus, Enterococcus faecalis e Staphylococcus sciuri subsp. lentus., which showed resistance to antibacterials, especially the E. faecalis isolate classified as MDR (multi drug resistant). In conclusion, the best form of diagnosis is the joint evaluation of several tests, both screening and confirmatory, in order to obtain a definitive diagnosis with assertiveness.
\end{abstract}

Keywords: Brucellosis; Brucella melitensis; Equine; Zoonotic disease.

\begin{abstract}
Resumo
Existem diversas enfermidades infectocontagiosas que acometem os equinos podendo causar grandes perdas econômicas nesse setor e danos ao bem estar dos animais. Nessa espécie, lesões abscedantes de caráter purulento preferencialmente na região da cernelha são fortemente sugestivas de brucelose. Entretanto são poucos os estudos realizados sobre a doença nessa espécie, dificultando sua identificação e controle devido à falta de padronização na interpretação dos resultados. Desse modo, foram coletados a partir de tres equinos, amostras de sangue total, soro e secreção purulenta. Os animais eram provinientes do estado do Pará. Os métodos de diagnóstico selecionados foram os testes do Antígeno Acidificado Tamponado (AAT) e Reação em Cadeia da Polimerase (PCR), mediante resultado molecular negativo para brucelose optou-se por análises microbiológicas. Os exames sorológicos de parte das amostras foram positivos para brucelose, porém todas apresentaram resultados negativos à PCR. No cultivo bacteriano foram isoladas as espécies Streptococcus equi subsp. zooepidemicus, Enterococcus faecalis e Staphylococcus sciuri subsp. lentus., os quais apresentaram resistência aos antibacterianos, em especial o isolado de $E$. faecalis classificado como MDR (resistência múltipla a drogas). Concluindo-se que a melhor forma de diagnóstico é a avaliação conjunta de diversos testes, tanto de triagem como confirmatórios, a fim de se obter um diagnóstico definitivo com assertividade.
\end{abstract}

Palavras-chave: Brucelose; Brucella melitensis; Equino, Doença zoonótica.

\title{
Resumen
}

Existen varias enfermedades infecciosas que afectan a los equinos y pueden causar grandes pérdidas económicas en este sector y daños al bienestar animal. En esta especie, las lesiones con abscesos de carácter purulento, preferentemente en la cruz, son muy sugestivas de brucelosis. Sin embargo, se han realizado pocos estudios sobre la enfermedad en esta especie, lo que dificulta su identificación y control por la falta de estandarización en la interpretación de los resultados. Por lo tanto, se recolectaron muestras de sangre completa, suero y secreción purulenta de tres caballos. Los animales procedían del estado de Pará. Los métodos de diagnóstico seleccionados fueron la prueba de placa del Rosa Bengala y la Reacción en Cadena de la Polimerasa (PCR), para los resultados moleculares negativos para brucelosis se eligió el análisis microbiológico. Aunque parte de las muestras resultaron positivas para brucelosis en las pruebas serológicas, todas arrojaron resultados negativos para la PCR. En cultivo bacteriano, se aislaron especies Streptococcus equi subsp. zooepidemicus, Enterococcus faecalis y Staphylococcus sciuri subsp. lentus., que mostró resistencia a los antibacterianos, especialmente al aislado de E. faecalis clasificado como multirresistente. En conclusión, la mejor forma de diagnóstico es la evaluación conjunta de varias pruebas, tanto de cribado como confirmatorias, para obtener un diagnóstico definitivo con asertividad.

Palabras clave: Brucelosis; Brucella melitensis; Equino; Enfermedad zoonótica.

\section{Introduction}

Brazil concentrates one of the largest equine herds in the world, with approximately 4,236,062 heads according to the

2017 census, of which an estimated 323,655 are in the state of Pará (IBGE, 2017; Silva et al., 2018). The Ministério da 
Agricultura, Pecuária e Abastecimento (MAPA), reports the growth of the sector, highlighting the increase in sales to 16 billion of Reais in 2016, according to a survey by Canal Rural (MAPA, 2009; MAPA, Equideocultura 2016; Barcelos et al., 2017). The equine species has great importance in the state, meeting the needs of transport and traction, handling buffaloes and cattle, in addition to having important performance in equestrian sports such as vaquejada (Ribeiro et al., 2008; Marques et al., 2016).

There are several infectious diseases that affect horses and can cause great economic losses in this sector and damage to the well-being of animals, including diseases of zoonotic potential such as glanders, leptospirosis and brucellosis (Barcelos et al., 2017; Rocha et al., 2019). In equines, purulent abscess lesions in bursae, ligaments, tendons, synoviums and joints, preferably in the withers are strongly suggestive of brucellosis, and reproductive disorders in this species are rare. Thus, economic damages resulting from brucellosis are considered lower when compared to other species of zootechnical interest, such as cattle and pigs in which brucellosis is considered a reproductive disease (Silva et al., 2018).

The isolation and identification of bacteria from cervical lesions is the gold standard for diagnosis, however the difficulty of this procedure and limitation for large-scale use has made the use of techniques such as the Rose-Bengal plate test (RBPT) and Standard Tube agglutination Test (SAT) more frequent due to the speed of the result and the low cost (Fernandes \& Gradela, 2014; Gharekhani et al., 2020). The most widely used serological method is the RBPT (recommended by PNCEBT) and in which the presence of agglutination, will classify the animal as reagent to the test, being able to be submitted to confirmatory tests. Non-reactive animals will be considered negative and positive animals will be destined for sanitary slaughter (Fernandes \& Gradela, 2014).

Conventional serological methods have low sensitivity during early stages of the disease and reduced specificity in areas where the disease is endemic (Asaad \& Alqahtani, 2012). In addition, the occurrence of nonspecific reactions, the lack of standardization in the interpretation of results and false positive results in the serological study of equines has been alerted (Brasil, 2006; Pinho et al., 2014; Paim et al., 2015). Thus, the importance of differential microbiological diagnosis in cases of abscesses in the withers and synovitis in equines is evidenced in order to avoid economic losses and risks to public health ( Silva et al., 2018). The present study aimed to identify the etiological agents of withers abscesses in equines from the state of Pará and to assess their susceptibility to antimicrobial drugs.

\section{Material and Methods}

The study was carried out from withers abscess samples from three horses of different origins, two from a property in Marajó and one from the metropolitan region of Belém. The animals were known to be positive in the RBPT performed in the field, according to the MAPA recommendations (Brasil, 2006), however, for confirmatory effect, the samples reacting to RBPT were submitted to retesting the conventional RBPT, according to the procedure adopted by Ribeiro et al., (2003) and to the Polymerase-mediated Chain Reaction (PCR) (Paim, et al., 2015).

The blood was collected by venipuncture of the jugular vein in a sterile tube with EDTA for PCR and in a sterile tube without anticoagulant for serology. Samples from Marajó were transported in a thermal box with recyclable ice at $-10{ }^{\circ} \mathrm{C}$ and the from Belém was sent directly to the laboratory (from veterinary microbiology at the Universidade Federal Rural da Amazônia), subsequently they were transferred to $1.5 \mu \mathrm{L}$ eppendorfs and kept in the ultra-freezer at $-80^{\circ} \mathrm{C}$. The secretions were collected from puncture with a sterile syringe and kept in sterile tubes between $6^{\circ} \mathrm{C}$ and $10^{\circ} \mathrm{C}$.

For DNA extraction two methods were used: the commercial kit PureLink TM Genomic DNA Mini Kit for blood according to the recommendations provided by the manufacturer and the extraction by Phenol-Chloroform method for secretions according to Sambrook et al., (1989). 
For PCR assay were used as 4F primers (5'- TGGCTCGGTTGCCAATATCAA -3 ') and 5R (5'CGCGCTTGCCTTTCAGGTCTG -3'), aiming amplification of a 223-bp region on the sequence encoding the 31-kDa immunogenic Brucella melitensis protein (gene BCSP31). Positive control were the bacterial DNA extracted from the B19 vaccine and negative control consisted of sterile deionized water. The reaction protocol was done according by Baily et al., (1992) and Queipo-Ortuño et al., (1997).

After the negative PCR assay result were the samples of purulent secretion was inoculated in base agar plus 5\% sheep blood and MacConkey agar, being in a bacteriological incubator at $37^{\circ} \mathrm{C}$ for 24 hours to isolate the etiological agent according by Ikram, (2005). The classification and identification of the genus of the microorganisms was carried out by through of the morphotintorial characteristics to the Gram staining, biochemicals and the macroscopy of the colonies, regarding the species, were identified by the automated method VITEK® 2.

The identified species were classified according to their sensitivity to antibacterials using the methodology proposed by Bauer, (1966). Demanding microorganisms were seeded on 5\% sheep blood agar plates. The antibiotic-impregnated discs were: amoxicillin + clavulanate $(10 \mu \mathrm{g})$, gentamicin $(10 \mu \mathrm{g})$, norfloxacin $(10 \mu \mathrm{g})$, oxacillin (1 $\mu \mathrm{g})$, penicillin (10 IU), cefotaxime $(30 \mu \mathrm{g})$, ampicillin $(2 \mu \mathrm{g})$, rifampin $(5 \mu \mathrm{g})$, azithromycin $(15 \mu \mathrm{g})$ and ciprofloxacin (30 $\mu \mathrm{g})$; isolates with intermediate susceptibility were classified as resistant and multi drug resistant (MDR) was defined as resistance to $\geq 3$ classes of antimicrobial drugs according to Johns and Adams, (2015).

\section{Results and Discussion}

All blood samples were reactive to the RBPT carried out in the field and when submitted to the re-test in the laboratory they presented the same results. Purulent secretions were also evaluated by the RBPT and only the animal sample from the metropolitan region was laboratory reagent, but none of the blood and secretion samples tested positive for Brucella spp. when applied to PCR assay (Figure 1).

Figure 1. Agarose gel electrophoresis analysis of PCR amplified DNA, in the figure the positive control $(\mathrm{C}+)$, negative control (C-) and the samples (A) are highlighted.

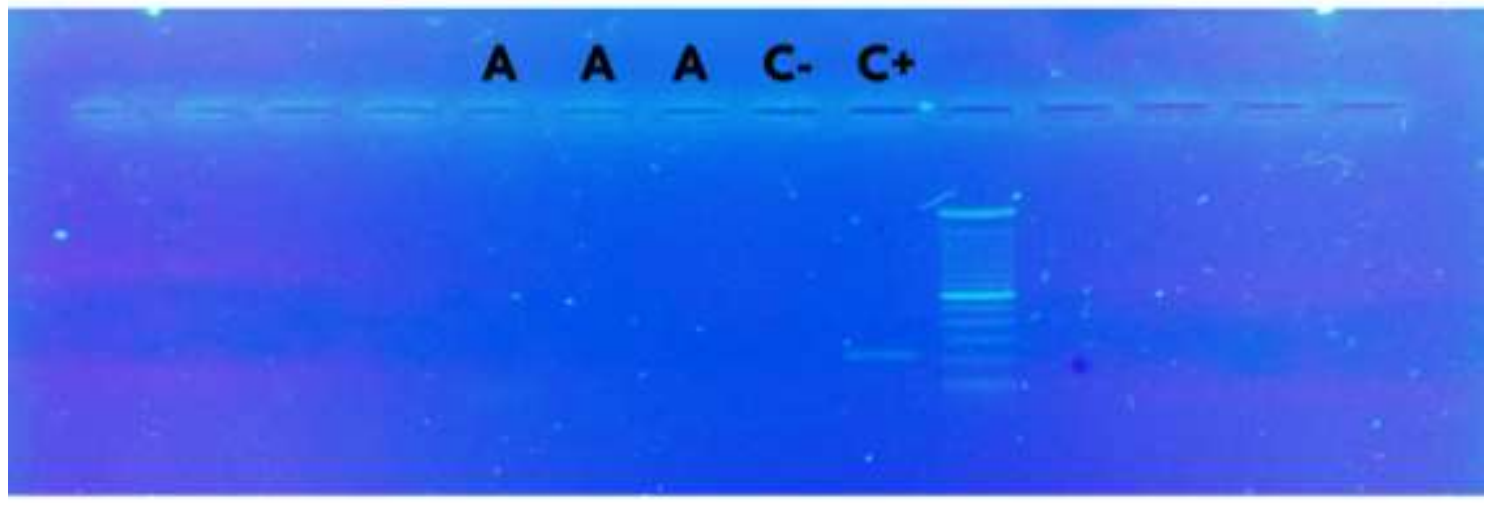

Source: Authors.

Result similar has been found by Meirelles-Bartoli \& Mathias (2020), which was a sensitivity of 99.6\% and a relative specificity of $83.9 \%$ of the RBPT (screening test) were found in relation to confirmatory tests, however Ribeiro et al., (2003) warns of the occurrence of nonspecific reactions, so that the serological diagnosis of brucellosis is more reliable when obtained through varied tests. 
Another relevant point is the lack of standardization in the interpretation of serological tests of the disease in horses, since the PNCEBT does not have detailed rules for serodiagnostic methods for equine brucellosis, causing difficulties in terms of sanitary conduct, control actions and prophylaxis of the disease in this species, as reported Ribeiro et al., (2008) and Pinho et al., (2014).

Due to the negative results in PCR for brucellosis, another etiology for abscesses was sought, opting for microbiological examination. The three samples showed positive growth on $5 \%$ sheep blood agar plates incubated at $37^{\circ} \mathrm{C}$ for 24 hours and were classified according to colony size, shape, color, hemolysis and presence of catalase.

Evidencing the importance of microbiological diagnosis in cases of withers abscesses and synovitis in the equine species, already documented by several authors such as Ribeiro et al., (2003) and Karthik et al., (2016), who recommend making the differential diagnosis for bacteria: Arcanobacterium pyogenes, Actinomyces bovis, Escherichia coli, Pseudomonas aeruginosa, Proteus mirablis and for the genus Pasteurella spp., Corynebacterium spp., Streptococus spp. e Staphylococus spp. which can also be isolated from fistulous abscesses in equines.

With light microscopy it was observed the presence of Gram positive cocci organized in chains (pearl necklace aspect) or pairs obteined in pure culture, which were identified by automated equipment due to their biochemical characteristics in the species Streptococcus equi, subsp. zooepidemicus, Enterococcus faecalis e Staphylococcus sciuri subsp. lentus. (Figure 2).

Figure 2. Photograph of colonies stained by the Gram technique of Streptococcus equi subsp. zooepidemicus (A), Enterococcus faecalis (B) and Staphylococcus sciuri subsp. lentus (C) in microscope slide (100x magnification).

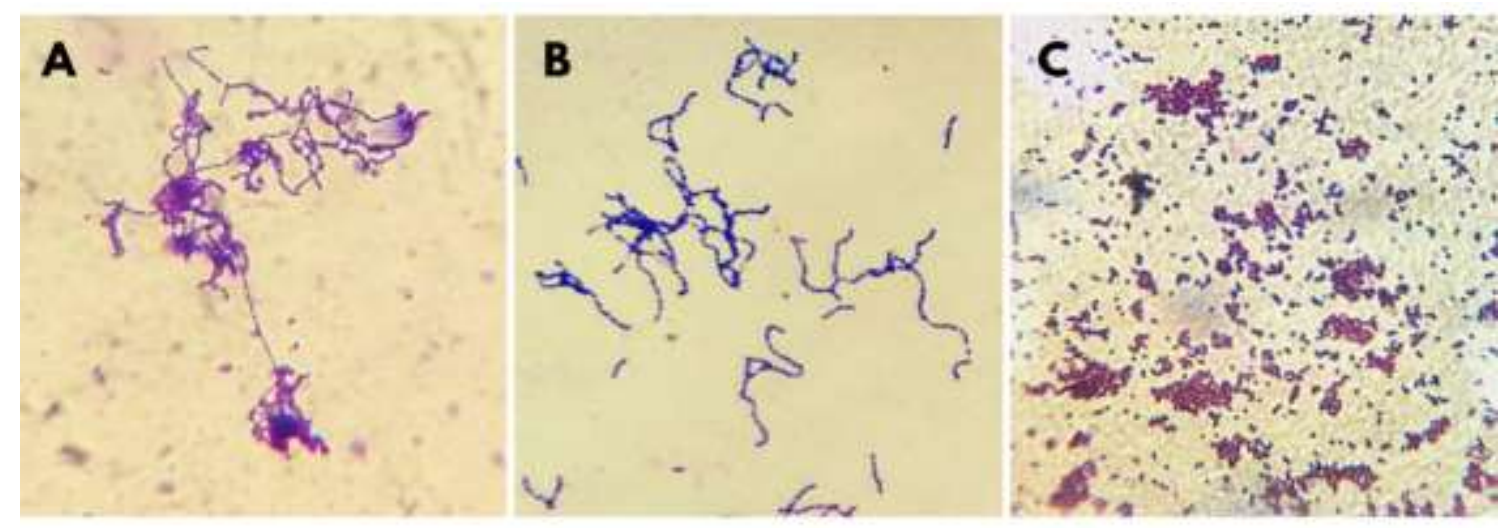

Source: Authors.

The descriptions of S. equi subsp. zooepidemicus were compatible with those of Moraes et al., (2009) that it is of $\beta$ hemolytic streptococcal species most frequently isolated from horses and the etiological agent of several pyogenic diseases in humans and animals, corroborating the report by Khurana \& Dhama, (2016) that the only pathogen S. zooepidemicus was isolated in diseases such as abortions, uterine inflammation, pneumonia, abscesses and joint infections.

Enterococcus are present as commensals in the gastrointestinal tract of most mammals, and according to CortésDelgadillo, (2007) they can behave as opportunistic pathogens causing infections, such as cases of diarrhea in foals and suppurative lesion conditions in adult equine in accordance with results of the present work.

Silva et al., (2013) characterizes Staphylococcus sciuri subsp. lentus as part of the commensal microbiota of mammalian skin, being isolated from healthy and sickness equine. However, Kengkoom \& Ampawong, (2017) described the first case of subcutaneous abscess and chronic dermatitis in rats associated with S. sciuri infection in Thailand. As in the report by Pessoa et al.,(2014), in which samples were collected from 28 abscesses, which no animal presented reactive serology for 
brucellosis. The nodule samples were then sown and the growth of Staphylococcus spp. It was obtained. However, little is known about the pathology and epidemiology of S. sciuri infections in animals.

The antibiotics of selection for microorganisms of the genus Streptococcus spp. they belong to the penicillin group (penicillin G, oxacillin, ampicillin, amoxicillin + clavulanate) and third generation cephalosporins (cefotaxime). Sulfonamides, although recommended as the first choice, were not used because infections with large amounts of debris do not respond well to treatment with this chemotherapy as documented by Spinosa et al., (2017).

Isolate of Streptococcus equi subsp. zooepidemicus was susceptible to cephalosporin and all penicillins used, except ampicillin, corroborating previous research of Pansani et al., 2016 that detected in equine samples 100\% of the isolates of the subspecies sensitive to penicillin, $40 \%$ resistant to ampicillin, however $35 \%$ presented resistance to cefotaxime, differently our study (Table 1).

Table 1. antibacterial sensitivity test results.

\begin{tabular}{cccc}
\hline & S. zooepidemicus & E. faecalis & S. lentus \\
\hline GTN & $\mathrm{R}$ & $\mathrm{R}$ & $\mathrm{R}$ \\
OXA & $\mathrm{S}$ & - & $\mathrm{R}$ \\
PG & $\mathrm{S}$ & $\mathrm{R}$ & $\mathrm{R}$ \\
AMP & $\mathrm{R}$ & $\mathrm{R}$ & $\mathrm{R}$ \\
AMC & $\mathrm{S}$ & $\mathrm{R}$ & - \\
NOR & $\mathrm{R}$ & - & $\mathrm{R}$ \\
CIP & $\mathrm{S}$ & $\mathrm{S}$ & - \\
CTX & $\mathrm{S}$ & $\mathrm{R}$ & - \\
RIF & $\mathrm{R}$ & - & - \\
AZM & - & $\mathrm{R}$ & $\mathrm{R}$ \\
TC & - & - & $\mathrm{S}$ \\
CAP & - & - & $\mathrm{S}$ \\
\hline
\end{tabular}

GTM (Gentamycin), OXA (Oxacillin), PG (Penicillin G), AMP (Ampicillin), AMC (Amoxicillin + clavulanate), NOR (Norfloxacin), CIP (Ciprofloxacin), CTX (Cephotaxime), RIF (Rifampicin), AZM (Azithromycin), TC (Tetracycline), SMX/TMP (Sulfamethoxazole-Trimethopim) e CAP (Chloramphenicol). Source: Authors.

The S. zooepidemicus strain showed resistance to norfloxacin and sensitivity to ciprofloxacin (both belonging to the fluoroquinolone class), in addition to MDR. Our results are similar to those of Johns \& Adams, (2015) who reported increased resistance to enrofloxacin and increased MDR, with the most common pattern being resistance to enrofloxacin, gentamicin and tetracyclines found in strains of the subspecies.

For the species Enterococcus faecalis the antibiotics of first choice are combinations of beta-lactams and aminoglycosides or cephalosporins aiming at the synergistic effect of these drugs, since these bacteria have intrinsic resistance to various antimicrobial therapies and the ability to acquire more resistance by genes introduced by plasmids and other resistance strategies as reported by Herdan et al., (2012).

Isolate presented MDR, being sensitive only to ciprofloxacin and resistant to all tested antibiotics of the penicillin, aminoglycoside, macrolides and cephalosporin class, similar data those of Herdan et al., (2012) who documented sensitivity to fluorquinolone enrofloxacin and resistance to other classes of antibiotics in samples of purulent discharges of septic synovitis 
in equine. Distinct to Kim et al., (2016) and Sukmawinata et al., (2018) who found only 1.1\% ampicillin resistance and 100\% susceptibility to ampicillin bacteria respectively.

The antibiotics of choice for microorganisms of the genus Staphylococcus spp. they are the groups of penicillins (penicillin G, ampicillin and oxacillin), macrolides (azithromycin) and sulfonamides, however sulfas were not used for the test due to their limited action on sample agents such as those of the present study. The S. sciuri strain was also resistant to multiple drugs in the classes of penicillins, macrolides, aminoglycosides and quinolones, so that all antimicrobials of first choice would be ineffective in combating this strain. Result in agreement by Salaberry et al., 2016, in which isolates of Staphylococcus spp. coagulase-negative demonstrated high resistance (above 50\%) to penicillin, oxacillin and ampicillin.

However, the microorganism has demonstrated sensitivity in vitro to drugs indicated as alternatives to antibiotic therapy in MDR cases by the FDA Clinical Indications, (2019).

\section{Conclusions}

Although withers abscesses are still one of the main indicative symptoms of brucellosis in the equine species, it is of utmost importance to carry out different types of tests to compare the results, both screening and confirmatory ones; molecular, microbiological or serological, aiming to arrive at the definitive diagnosis with assertiveness and obtain success in the treatment of the disease when it is possible, avoiding the dissemination of multiresistant genes in bacteria. Thus, avoiding economic losses, risks to public health and the unnecessary sacrifice of animals.

\section{References}

Asaad, A. M., \& Alqahtani, J. M. (2012). Serological and molecular diagnosis of human brucellosis in Najran, Southwestern Saudi Arabia. Journal of infection and public health, 5(2), 189-194.

Barcelos, E. P. (2017) Relatório do estágio curricular supervisionado em Medicina Veterinária-área: manejo e reprodução equina.

CLSI. (2019). Suggested Grouping of US-FDA Approved Antimicrobial Agents that should be considered for Routine testing and reporting on nonfastidious organisms by clinical laboratories. 29ed. CLSI guideline M100-S29. Wayne, PA: Clinical and Laboratory Institute.

Cortés-Delgadillo, F. J. (2007). Terapia con antimicrobianos en equinos. Revista de Sanidad Militar, 61(1), 45-54.

Fernandes, F. S., \& Gradela, A. (2014). Brucelose em uma égua doadora de embriões: Relato de Caso. Ciência Veterinária, 54.

Gharekhani, J., Barati, E., Doulatshahi, E. A., Talaei, M., \& Rasouli, M. R. (2020). Brucella Infection in Horses From Hamedan Province, Iran. Avicenna Journal of Clinical Microbiology and Infection, 7(2), 60-62.

Herdan, C. L., Acke, E., Dicken, M., Archer, R. M., Forsyth, S. F., Gee, E. K., \& Pauwels, F. E. T. (2012). Multi-drug-resistant Enterococcus spp. as a cause of non-responsive septic synovitis in three horses. New Zealand veterinary journal, 60(5), 297-304.

Ikram, M. (2005). Microbiologia diagnóstica. In: HENDRIX, C. M. Procedimentos laboratoriais para técnicos veterinários. 4. ed. São Paulo: Roca. p. 109-225.

Johns, I.C., \& Adams, E. L. (2015). Trends in antimicrobial resistance in equine bacterial isolates: 1999-2012. Veterinary Record, v. 176 , n. 13, p. 334-334.

Karthik, K., Prabakar, G., Bharathi, R., \& Kumar, S. (2016). Equine Brucellosis: Review on epidemiology, pathogenesis, clinical signs, prevention and control. J. Exp. Biol. Agric. Sci, 4, 151-160.

Kengkoom, K., \& Ampawong, S. (2017). Staphylococcus sciuri associated to subcutaneous abscess and dermatitis in ICR mouse. Arquivo Brasileiro de Medicina Veterinária e Zootecnia, 69, 117-122.

Khurana SK \& Dhama K (2016) Brief overview: bacterial diseases of equines. IAB, p. 26.

Kim, D. H., Chung, Y. S., Park, Y. K., Yang, S. J., kyung Lim, S., Park, Y. H., \& Park, K. T. (2016). Antimicrobial resistance and virulence profiles of Enterococcus spp. isolated from horses in Korea. Comparative immunology, microbiology and infectious diseases, 48, 6-13.

Marques, J. R. F., Figueiró, M. R., Saraiva, N. Z., Leal, R. P., Sales, R. L., \& Costa, M. R. (2016). Equinos em conservação na Ilha de Marajó, Amazônia, Brasil. Embrapa Amazônia Oriental-Artigo em periódico indexado (ALICE).

Meirelles-Bartoli, R. B., \& Mathias, L. A. (2020). Estudo comparativo entre os testes adotados pelo PNCEBT para o diagnóstico sorológico da brucelose em bovinos. Arquivos do Instituto Biológico, 77, 11-17.

Moraes, C. M. D., Vargas, A. P. C. D., Leite, F. P. L., Nogueira, C. E. W., \& Turnes, C. G. (2009). Adenite equina: sua etiologia, diagnóstico e controle. Ciência Rural, 39, 1944-1952. 
Paim, K. P., Soares, M. M., Pereira, P. C., Junqueira Júnior, D. G., Souza, M. A., Moreira, R. Q. \& Lima, A. M. C. (2015). Investigação de Brucella abortus no sêmen e anticorpos anti-brucella spp. no soro de garanhões. Ciência \& Tecnologia Fatec-JB, v. 7, n. esp.

Pansani, A. M., Gatto, I. R. H., Frias, D. F. R., \& Kozusny-Andreani, D. I. (2016). Prevalência e resistência a antibióticos de (Streptococcus equi) da cavidade nasal de equinos hígidos no município de Fernandópolis, São Paulo, Brasil. Acta Veterinaria Brasilica, 10(2), $144-149$.

Pessoa, A. F. A., Pessoa, C. R. M., Miranda Neto, E. G., Dantas, A. F. M., \& Riet-Correa, F. (2014). Doenças de pele em equídeos no semiárido brasileiro. Pesquisa Veterinária Brasileira, 34, 743-748.

Pinho, A. P. V. B., Kuroda, R. B. S., Vasconcellos, S. A., Neto, J. S. F., Ossada, R., de Souza, V. A. F. \& de Moraes, C. C. G. (2014). Estudo sorológico da brucelose e leptospirose em equídeos da ilha de Maiandeua (Algodoal) no Estado do Pará. Semina: Ciências Agrárias, 35(6), $3221-3229$.

Queipo-Ortuño, M. I., Morata, P., Ocon, P., Manchado, P., \& Colmenero, J. D. D. (1997). Rapid diagnosis of human brucellosis by peripheral-blood PCR assay. Journal of clinical microbiology, 35(11), 2927-2930.

Ribeiro, M. G., Nardi Júnior, G., Megid, J., Paes, A. C., \& Listoni, F. J. P. (2003). Aglutininas anti-Brucella abortus no soro e em secreção de bursite cervical em eqüinos. Arquivo Brasileiro de Medicina Veterinária e Zootecnia, 55, 99-101.

Ribeiro, M. G., Motta, R. G., \& Almeida, C. A. S. (2008). Brucelose equina: aspectos da doença no Brasil. Rev. Bras. Reprod. Anim, 32, 83-92.

Rocha, K.S., Paz, G. S., Nascimento Guerreiro, A., Meneses, A. M. C., Marques, J. R. F., \& Moraes, C. C. G. (2019). Pesquisa de anticorpo anti-Leptospira spp. e anti-Brucella spp. em equinos provenientes da Ilha do Marajó, Pará. Revista Acadêmica Ciência Animal, 17, 1-6.

Salaberry, S. R. S., Saidenberg, A. B. S., Zuniga, E., Gonsales, F. F., Melville, P. A., \& Benites, N. R. (2016). Análise microbiológica e perfil de sensibilidade do Staphylococcus spp. em mastite subclínica de caprinos leiteiros. Arquivo Brasileiro de Medicina Veterinária e Zootecnia, 68(2), $336-344$.

Sambrook, J., Fritsch, E.F. \& Maniatis, T. (1989). Molecular cloning: a laboratory manual. 2.ed. New York: Cold Spring Harbor Laboratory Press. 628 p.

Silva, A.C.C. (2013). Caracterização de Staphylococcus do grupo sciuri e analise fenogenotípica da resistência à oxacilina em isolados de roedores e equinos do Instituto Biológico do Exército.

Silva, J. S. V., Nardi Junior, G., \& Martins, E. A. (2018). Brucelose Equina e o Agronegócio. In Vii Jornacitec-Jornada Científica e Tecnológica.

Spinosa, H.S., Górniak, S. L., Bernardi, M. M. (2017). Farmacologia aplicada à medicina veterinária. Rio de, 6 ed. 2017.

Sukmawinata, E., Sato, W., Uemura, R., \& Sueyoshi, M. (2018). Antimicrobial resistant Enterococcus faecium, Enterococcus faecalis, and other Enterococcus species isolated from foal feces in Japan. Journal of Equine Veterinary Science, 63, 51-54. 